\title{
PREPARATION OF TRANSPARENT HYDROXYAPATITE CERAMICS BY SPARK PLASMA SINTERING AND CELL CULTURE TEST
}

\author{
Daisuke Kawagoe $^{1 *}$, Yoshihiro Koga ${ }^{1}$, Emile Hideki Ishida ${ }^{1}$, Noriko Kotobuki ${ }^{2}$, \\ Hajime Ohgushi ${ }^{2}$ and Koji Ioku ${ }^{1 * *}$ \\ (*kawagoe@oyama -ct.ac.jp, **ioku@mail.kankyo.tohoku.ac.jp) \\ ${ }^{1}$ Graduate School of Environmental Studies, Tohoku University, \\ Aoba 6-6-20 Aramaki, Aoba-ku, Sendai 980-8579, Japan.
}

* now with Department of Material and Bioengineering, Oyama National College of Technology

771 Nakakuki, Oyama 323-0806, Japan.

${ }^{2}$ Research Institute for Cell Engineering, National Institute of Advanced Industrial Science and Technology, 3-11-46 Nakoji, Amagasaki 661-0974, Japan.

Keywords: Hydroxyapat ite, Spark plasma sintering, Transparent ceramics, Densification behavior, Cell culture dish

\begin{abstract}
Calcium hydroxyapatite, $\mathrm{Ca}_{10}\left(\mathrm{PO}_{4}\right)_{6}(\mathrm{OH})_{2}: \mathrm{HA}$, is the inorganic principle component of natural bones and teeth. It has been already suggested that the amount of $\mathrm{OH}$ ion in the crystal structure of $\mathrm{HA}$ is closely related to the biocompatibility. The amount of $\mathrm{OH}$ ion in current $\mathrm{HA}$, however, has not been controlled. In order to prepare more functional $\mathrm{HA}$ ceramics, the amount of $\mathrm{OH}$ ion must be controlled. In this study, HA ceramics with different $\mathrm{OH}$ amount were prepared by spark plasma sintering (SPS). In order to reveal the ideal sintering conditions for preparation of transparent ceramics, densification process on SPS was investigated. The samples were pressed uniaxialy under $60 \mathrm{MPa}$, and then they were heated by SPS at $800{ }^{\circ} \mathrm{C}, 900{ }^{\circ} \mathrm{C}$ and $1000{ }^{\circ} \mathrm{C}$ for 10 min with the heating rate of $25^{\circ} \mathrm{C}$ ? $\mathrm{min}^{-1}$. The quantity of $\mathrm{OH}$ ion in HA ceramics sintered by SPS was decreased with increasing temperature of sintering. Transparent HA ceramics were prepared by SPS at $900{ }^{\circ} \mathrm{C}$ and $1000{ }^{\circ} \mathrm{C}$. In analysis of the densification behavior during sintering of HA by SPS, dominant sintering mechanism was plastic flow of densification. Cell attachment, proliferation, and osteogenic differentiation of rat mesenchymal stem cells on transparent HA ceramics observed by light microscopy were significantly similar to those on tissue culture polystyrene dish. The observation of living cells on transparent HA ceramics is a new significant and revealed reliable nature of the hydroxyapatite ceramics for the purpose of tissue engineering in hard tissue repair.
\end{abstract}

(Received April 28, 2006; Accepted December 15, 2006)

\section{INTRODUCTION}

Calcium hydroxyapatite, $\mathrm{Ca}_{10}\left(\mathrm{PO}_{4}\right)_{6}(\mathrm{OH})_{2}: \mathrm{HA}$, is the inorganic principle component of natural bones and teeth. This material has the attractive feature of biocompatibility for the human hard tissue, therefore, many clinical applications of HA were carried out as artificial bones and teeth roots ${ }^{1-5}$.

Comparing to the conventional sintering method, spark plasma sintering (SPS) enables the ceramics to densify at lower temperatures and shorter duration by charging the intervals among powder particles with electrical energy and efficiently applying a high temperature spark plasma momentarily ${ }^{6,7}$. SPS can be an effective method to prepare HA ceramics ${ }^{8,9}$.

The objective of this study is preparation of the ideal samples to investigate the behavior of human cells on the surface of ceramics of HA. Direct observation of cultured cells on various materials has benefit for assessment of fundamental cellular functions including cell attachment, spreading, proliferation and differentiation on the materials.

In this study, to reveal the ideal sintering conditions for preparation of transparent ceramics, effects of plastic flow on SPS were investigated.

It has been already suggested that the amount of $\mathrm{OH}$ ion in the crystal structure of HA is closely related to the biocompatibility, the ability for bone formation and the ionic conductivity. The amount of $\mathrm{OH}$ ion in current HA, however, has not been controlled ${ }^{10}$. In the past papers, Fujimori and Ioku et al. reported that the amount of $\mathrm{OH}$ ion in HA was controllable by the control of heating conditions ${ }^{11}$.

The present study deals with the preparation of HA ceramics with a different $\mathrm{OH}$ amount by SPS.

Current technology enables the regeneration of viable tissues or organs by using both cultured cells and suitable scaffolds. HA is a well-known scaffold material and plays important roles in the adhesion, proliferation, and differentiation of cultured cells, especially bone-related cells. Ohgushi et al. have 
previously reported that mesenchymal stem cells (MSC) derived from bone marrow can be cultured on HA ceramics 12, 13. Significantly, under osteogenic conditions, the cultured MSC further differentiate into osteoblasts, which fabricate bone matrices on the HA ceramic surfaces. The cultured osteoblast/matrix constructs can show in vivo osteogenic capability as evidenced by new bone formation after in vivo implantation 14-16. Therefore, the tissue-engineered construct fabricated by cultured osteoblasts on a scaffold could be defined as regenerative cultured bone tissue ${ }^{17}$. Regenerative cultured bone tissue has already been applied clinically to patients such as in bone tumor cases. Thus, MSC cultured on various ceramics, in particular HA ceramics, has clinical significance. However, due to the nontransparency of the ordinary HA ceramics, analysis of the cellular mechanisms that lead to in vitro bone formation is observed.

Recently, enhanced green fluorescent protein (EGFP)-expressing transgenic rat has become available. The luminescence has caused researchers to use the gene of the protein for real-time bio-imaging monitoring. The cells we used were cultured mesenchymal stem cells derived from the EGFP-expressing transgenic rat bone marrow. As described, because the EGFP-expressing gene affects both fresh as well as cultured cells, the cells fluoresce in green under UV light. This enables clear observation of the shape of cultured cells by using fluorescence microscopy.

In this paper, the MSC derived from EGFP transgenic rat were cultured on transparent $\mathrm{HA}$ ceramics as well as on a polystyrene culture dish and were observed under light and fluorescence microscopy. Osteogenic differentiation of the MSC resulting in in vitro bone formation was analyzed both morphologically and biochemically.

\section{SINTERING PROCESS}

HA powder (High-purity grade, Ube Materials, Japan) of about $0.5 \mathrm{~g}$ was poured into a graphite mold (inner diameter $8 \mathrm{~mm}$ ), and then sintered by SPS method (SPS: Dr.Sinter-511S, Sumitomo Coal Mining, Japan). Schematic of SPS were shown in Fig. 1.

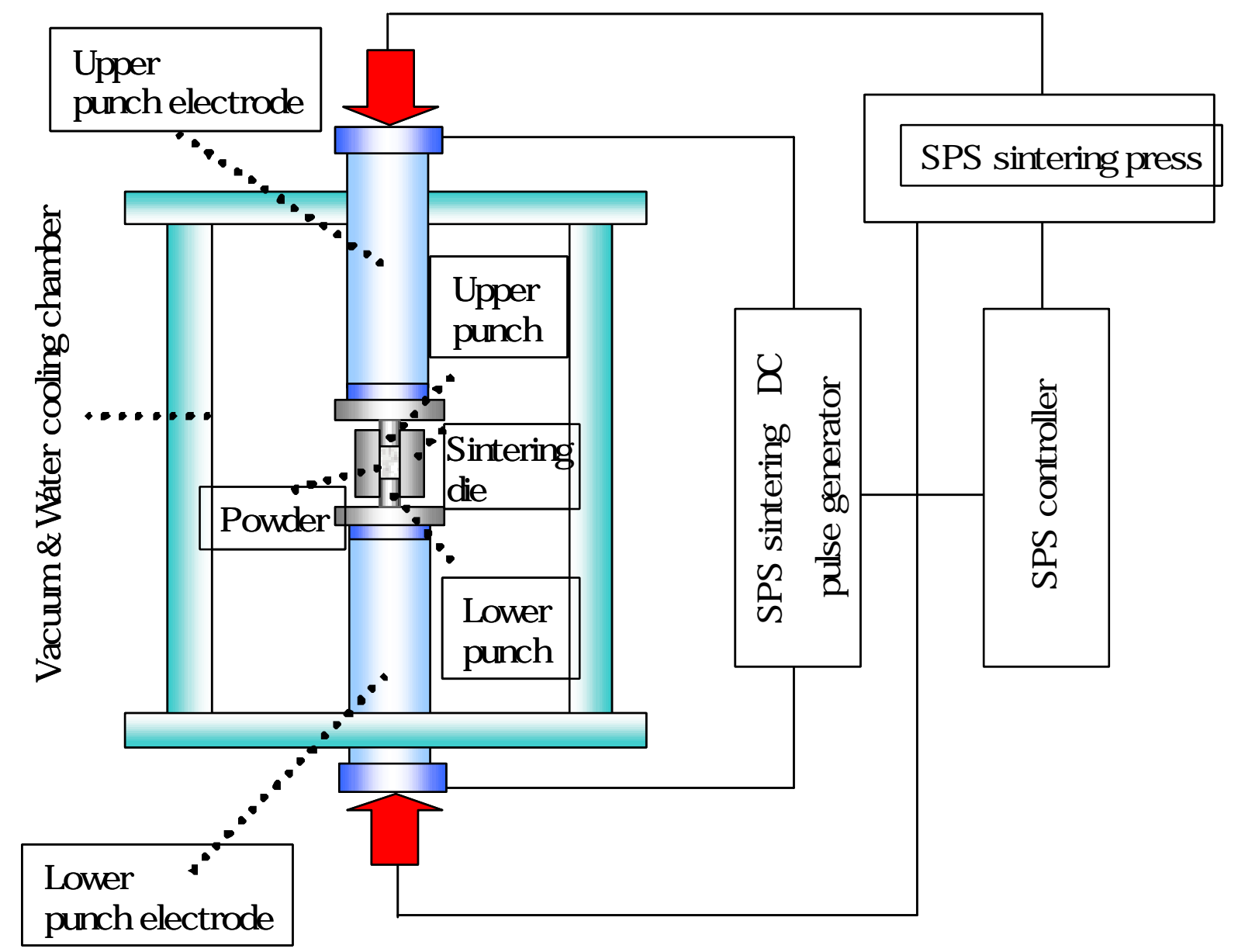

Fig. 1 Apparatus of spark plasma sintering. 
From the densification behavior of HA during sintering by SPS, ln (1-?) were plotted against sintering period according to the Murray's equations ${ }^{18-20}$ on SPS at $800^{\circ} \mathrm{C}$.

$$
\ln (1-?)=-3 s t / 4 ?+c .
$$

where ? is relative density, $\mathrm{s}$ is applied stress, $\mathrm{n}$ is viscosity coefficient, $\mathrm{t}$ is hold time and $\mathrm{C}$ is constant.

The temperature of samples during sintering were measured by thermocouples of $\mathrm{Rh} / \mathrm{Pt}-\mathrm{Pt}$, they were inserted into the wall of the graphite mold to measure the sample temperature. The samples were pressed under $60 \mathrm{MPa}$, and then they were heated at $800^{\circ} \mathrm{C}$, $900{ }^{\circ} \mathrm{C}$ and $1000{ }^{\circ} \mathrm{C}$ for $10 \mathrm{~min}$ with a heating rate of $25^{\circ} \mathrm{C}$ ? $\mathrm{min}^{-1}$.

\section{MATERIALS CHARACTERIZATION}

The starting powder and the obtained ceramics were identified by a powder X-ray diffractometer with graphite-monochromatized $\mathrm{CuKa}$ radiation, operated at $40 \mathrm{kV}$ and $20 \mathrm{~mA}$ (XRD; Geiger flex 2027, Rigaku, Japan). The morphology of particles was observed by transmission electron microscopy. The ceramics were polished with using a 4000-grid $\mathrm{SiC}$ and then polished finely with using a paste containing $\mathrm{a}-\mathrm{Al}_{2} \mathrm{O}_{3}$ fine particles smaller than $0.5 \mu \mathrm{m}$ in size. Density measurements based on Archimedes' principle were conducted. Theoretical density of HA was assumed to be $3.16 \mathrm{~g} \mathrm{~cm}^{-3}$. The hardness of samples was evaluated by an indentation method using the Vickers hardness tester (Model AVK-AII; Akashi, Japan) at the load of $3 \mathrm{~N}$ for $10 \mathrm{~s}$. The amount of $\mathrm{OH}$ ion in the ceramics was analyzed quantitatively by nuclear magnetic resonance (FT-NMR; Chemagnetics CMX300, Div. of Varian) and infrared spectroscopy (FT-IR; Spectrum 2000, Perkin Elmer). Thermogravimetry-differential thermal analysis (TG-DTA; TG-DTA32, Seiko Instruments Inc. Japan) was executed under the following condition: a- $\mathrm{Al}_{2} \mathrm{O}_{3}$ reference, and a heating rate of $10^{\circ} \mathrm{C}$ ? $\mathrm{min}^{-1}$ from room temperature to $1200{ }^{\circ} \mathrm{C}$. After thermal etching at the temperature $10{ }^{\circ} \mathrm{C}$ below sintering temperature for $10 \mathrm{~min}$, the surface of ceramics was observed by means of scanning probe microscopy (SPM; Nanopics 2100, Seiko Instruments, Japan) and using a field emission scanning microscopy (FE-SEM; JSM 820, JEOL, Japan). The sessile contact angles (SCA) of the HA ceramics and tissue culture polystyrene dishes were determined using Milli-Q water and a goniometer (Face Contact-Angle Meter, Kyowa Kaimenkagaku Co. Ltd., Tokyo, Japan). To evaluate the surface structures of the materials, a scanning electron microscope (SM-300, TOPCON CORPORATION) was used to analyze the surface of each material. Prior to being placed in the test chamber, the specimens were coated with 200.

\section{CULTURE METHODS}

Rat bone marrow cell plugs were obtained from 7 week-old female Sprague-Dawley (SD) rats that were EGFP transgenic rats ("green rat CZ-004", SD TgN (act-EGFP) QbCZ-004; Japan SCL Inc., Shizuoka, Japan). The EGFP absorbs light in the UV-blue region $(400 \mathrm{~nm})$, and emits light in the green $(510 \mathrm{~nm})$, facilitating observation of the shape of the transgenic cells using fluorescence microscopy. Preparation and osteogenic differentiation of MSC from the rat were described by Maniatopoulos et al. ${ }^{21}$ and modified by Ohgushi et al. ${ }^{22}$. In brief, rat bone marrow cells were flushed out by a culture medium, minimum essential medium (MEM, Nacalai Tesque Inc., Kyoto, Japan) containing $15 \%$ fetal bovine serum (FBS, JRH Biosciences Inc., KS, USA) and $1 \%$ antibiotics. These bone marrow cells were cultured in a humidified atmosphere of $95 \%$ air with $5 \% \mathrm{CO}_{2}$ at $37{ }^{\circ} \mathrm{C}$. The adherent mesenchymal stem cells (MSC) from rat bone marrow were initially cultured up to $80 \%$ confuence in T-75 asks (Becton, Dickinson and Company (BD), NJ, USA) and resuspended to $5 \times 10^{5}$ cells $/ \mathrm{ml}$ in culture medium following harvesting using $0.05 \%$ trypsin/ $0.53 \mathrm{mM}$ EDTA. The cell suspension was applied to sterilized, transparent HA ceramic disks ( $5 \mathrm{~mm}$ in diameter $\times 3 \mathrm{~mm}$ thick), which were placed into a 24-well plate, and on tissue culture polystyrene dishes $(\phi 35 \mathrm{~mm}, \mathrm{BD})$ as a control. These cells were cultured with osteogenic medium containing $10 \mathrm{nM}$ dexamethasone (Sigma-Aldrich Corporation, MO, USA), $10 \mathrm{mM}$ bglycerophosphate (Merck, Darmstadt, Germany) and $0.28 \mathrm{mM}$ ascorbic acid two-phosphate magnesium salt nhydrate (Sigma-Aldrich Corp.). The culture medium was changed two or three times per week. During the culture period, the cell morphologies were detected by phase-contrast and fluorescence microscopy.

\section{ALKALINE PHOSPHATASE(ALP) ACTIVITY STAINING}

The cultured cells on the transparent HA ceramics were rinsed with phosphate buffer saline (PBS) and fixed with $4 \%$ paraformaldehyde for $10 \mathrm{~min}$ at $4{ }^{\circ} \mathrm{C}$. The fixed cells were soaked in $0.1 \%$ naphthol AS-MX phosphate and $0.1 \%$ fast red violet LB salt in $56 \mathrm{mM}$ 2-amino-2-methyl- 1,3-propanediol (pH 9.9) for $10 \mathrm{~min}$ at room temperature and washed with PBS 22

\section{CALCIUM STAINING BY ALIZARIN RED S}

The cultured cells on the ceramics were washed with PBS and fixed with $4 \%$ paraformaldehyde for 10 min at $4{ }^{\circ} \mathrm{C}$. The fixed cells were soaked in $0.5 \%$ 
Alizarin red S/PBS for $10 \mathrm{~min}$ at room temperature and washed with PBS ${ }^{22}$.

\section{RESULT AND DISCUSSION}

The quantitative chemical analysis gave a $\mathrm{Ca} / \mathrm{P}$ molar ratio very closed to the correct HA stoichiometry $(\mathrm{Ca} / \mathrm{P}=1.67)$. There were little impurities as follows; $\mathrm{Sr}<8.9, \quad \mathrm{Si}<6.6, \quad \mathrm{Mg}<6.0$, $\mathrm{Na}<5.0, \mathrm{~K}<5.0, \mathrm{Fe}<0.9, \mathrm{Cu}<0.7, \mathrm{Mn}<0.2, \mathrm{Ba}<0.1$, $\mathrm{Ni}<0.1, \mathrm{Cd}<0.1$ ppm.

The particle size along long axis of HA powder was less than $0.1 \mu \mathrm{m}$ by TEM observation (Fig. 2). The size and shape of particles were relatively homogeneous.

In analysis of densification process of HA on SPS (Fig. 3), dominant sintering mechanism of SPS was plastic flow. Therefore, for preparation of transparent HA ceramics, the samples were pressed under $60 \mathrm{MPa}$ as maximal pressure in this process.

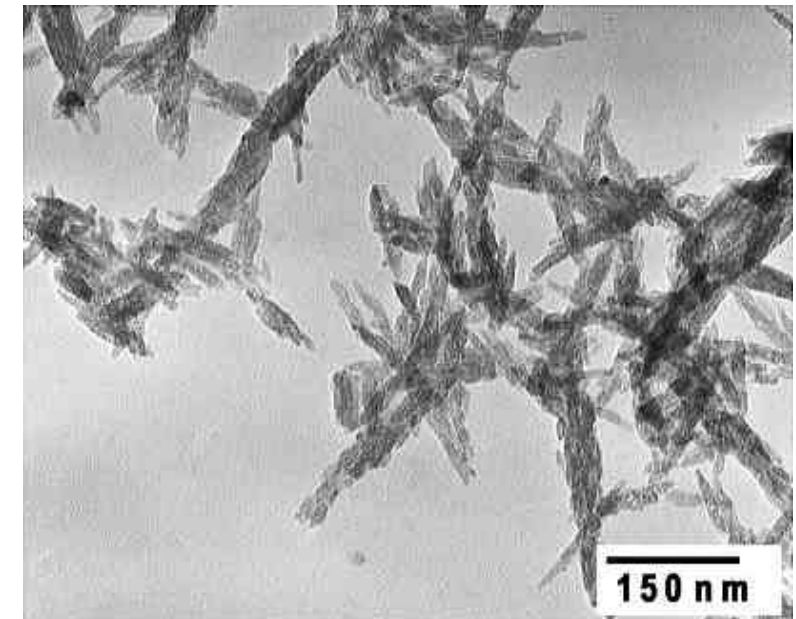

Fig. 2 TEM photograph of starting powder of HA.

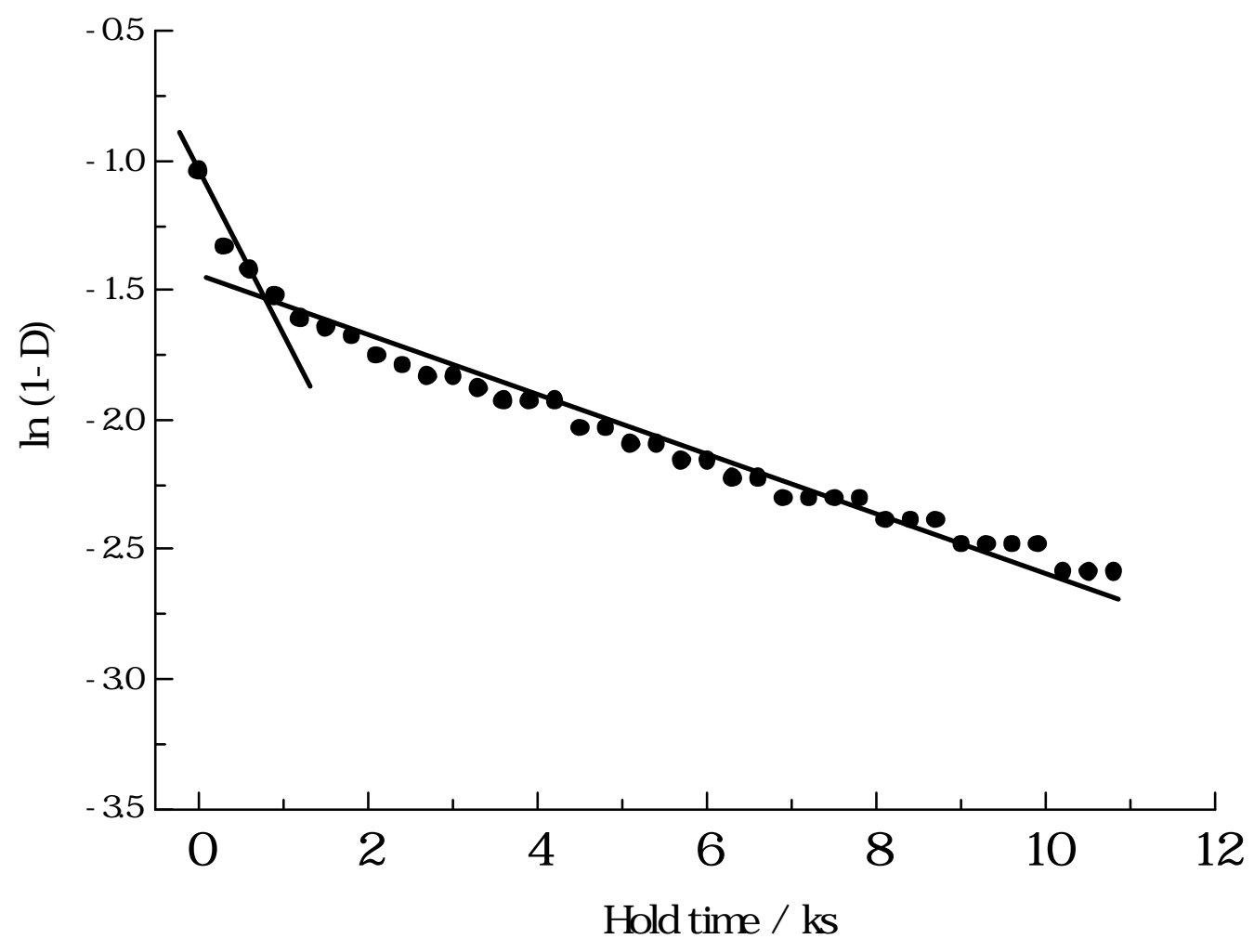

Fig. 3 Isothermal shrinkage behavior of HA heated at $800^{\circ} \mathrm{C}$ by SPS. 
No phases other than HA were revealed by XRD for the starting samples and samples after sintering by SPS at $800^{\circ} \mathrm{C}, \quad 900{ }^{\circ} \mathrm{C}$ and $1000{ }^{\circ} \mathrm{C}$ for $10 \mathrm{~min}$ (Fig. 4).

The spectrum of FT-IR indicates the presence of $\mathrm{OH}^{-}$in the starting powder and also in the prepared ceramics (Fig. 5). The band due to the stretching vibrations of $\mathrm{OH}$ ion appears at $3571 \mathrm{~cm}^{-1} 23$. The quantity of $\mathrm{OH}$ in HA ceramics sintered by SPS was decreased with increasing temperature of sintering. According to FT-IR and TG-DTA, the HA ceramics prepared at $800{ }^{\circ} \mathrm{C}$ was $\mathrm{OH}$ fully containing $\mathrm{HA}$ and the ceramics prepared at $900{ }^{\circ} \mathrm{C}$ was oxyhydroxyapatite $\quad\left(\mathrm{Ca}_{10}\left(\mathrm{PO}_{4}\right)_{6}(\mathrm{OH})_{1.2} \mathrm{O}_{0.4} ?_{0.4}\right.$, where? is a neutral vacancy in the $\mathrm{OH}$ site).

Transparent HA ceramics were obtained by SPS at $900{ }^{\circ} \mathrm{C}$ and $1000^{\circ} \mathrm{C}$ for $10 \mathrm{~min}$ (Fig. 6).

According to the FE-SEM observation, the ceramics prepared at $800{ }^{\circ} \mathrm{C}$ had a few pores of about $0.1 \mu \mathrm{m}$ in size. The FE-SEM photograph of transparent ceramics prepared at $900{ }^{\circ} \mathrm{C}$ after etching is shown in Fig.7. Average grain size of the ceramics sintered at $900{ }^{\circ} \mathrm{C}$ were around $0.15 \mu \mathrm{m}$. There were almost no pores in the ceramics.

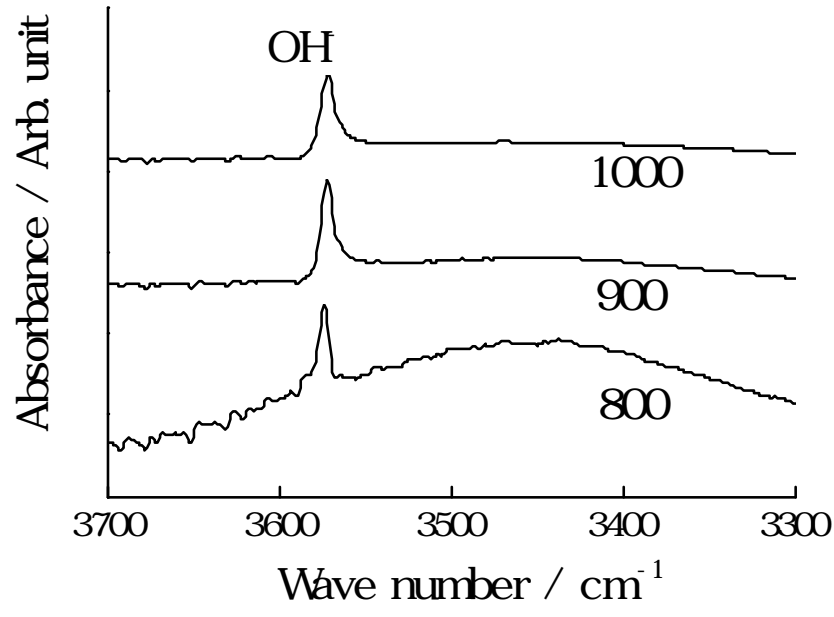

Fig. 5 IR spectra of HA ceramics prepared by SPS at $800{ }^{\circ} \mathrm{C}, 900{ }^{\circ} \mathrm{C}$ and $1000{ }^{\circ} \mathrm{C}$.

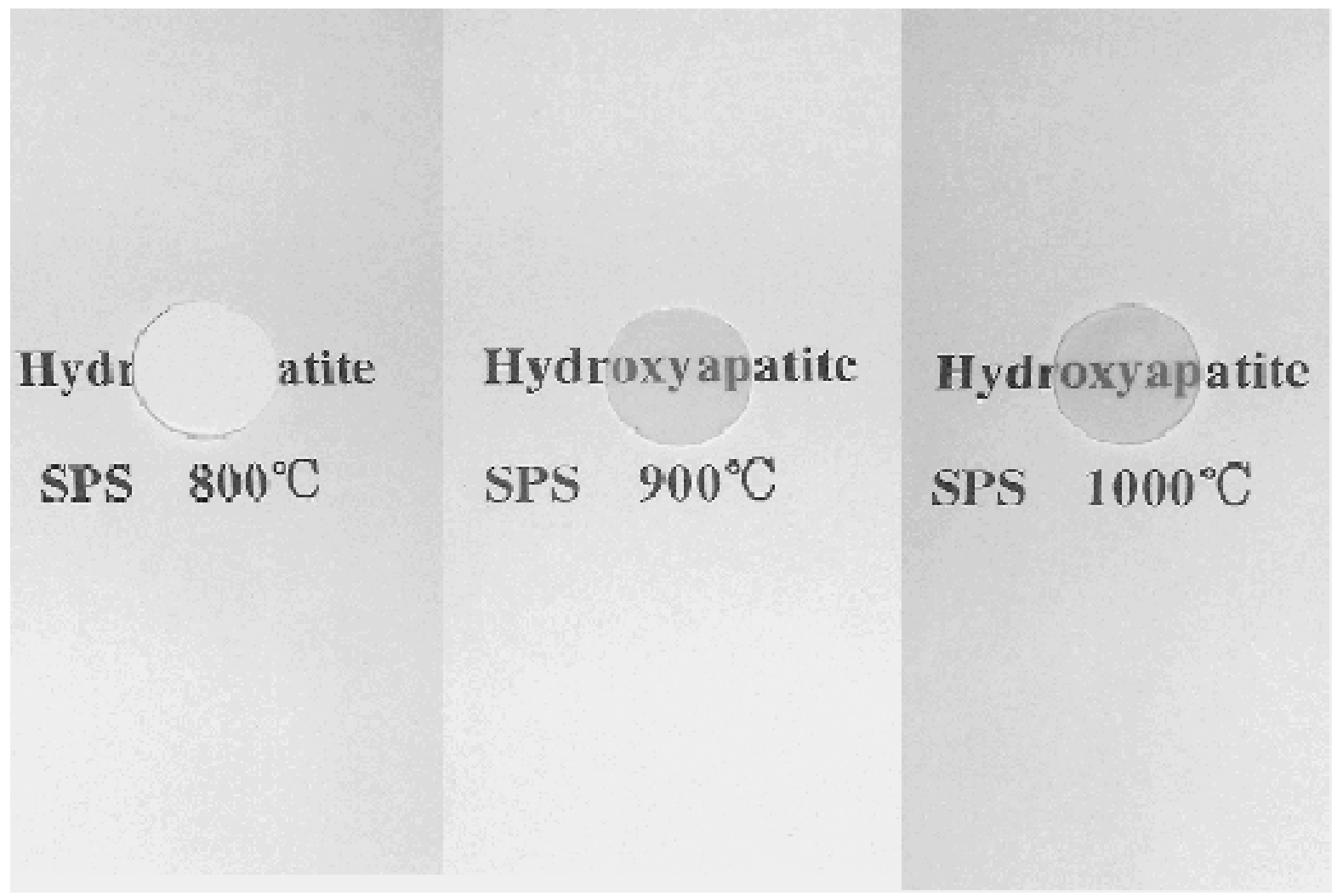

Fig. $6 \mathrm{OH}$-controlled HA ceramics prepared by SPS at $800{ }^{\circ} \mathrm{C}, 900{ }^{\circ} \mathrm{C}$ and $1000{ }^{\circ} \mathrm{C}$. 

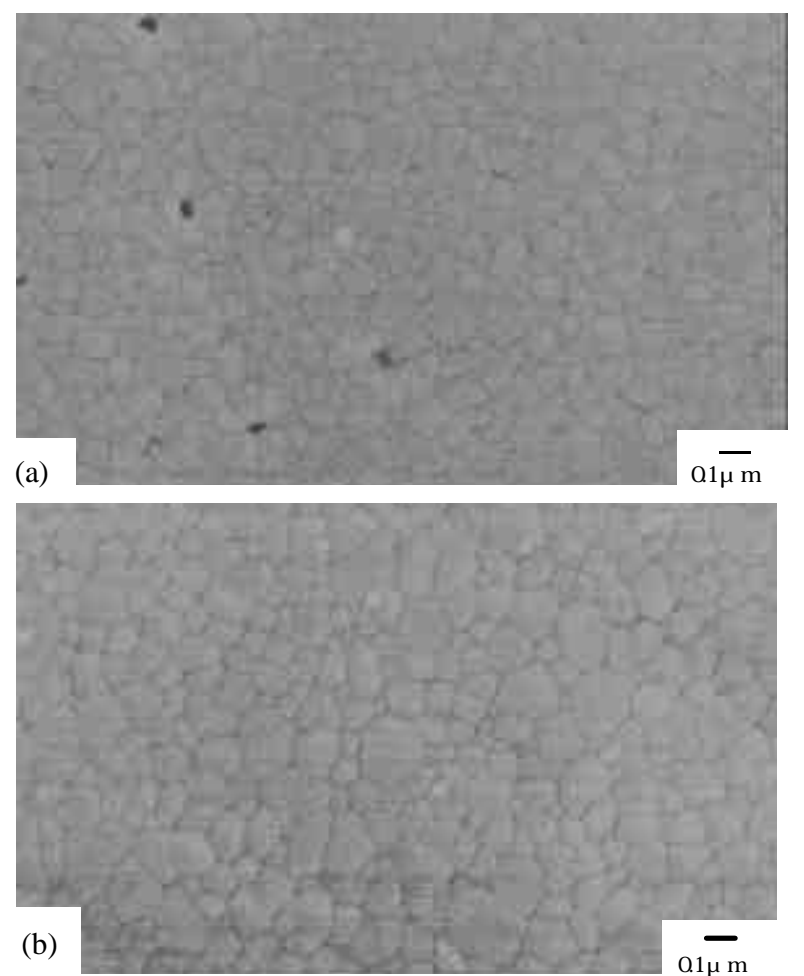

Fig. 7 SEM photographs of ceramics prepared by SPS at (a) $800{ }^{\circ} \mathrm{C}$ and (b) $900{ }^{\circ} \mathrm{C}$.

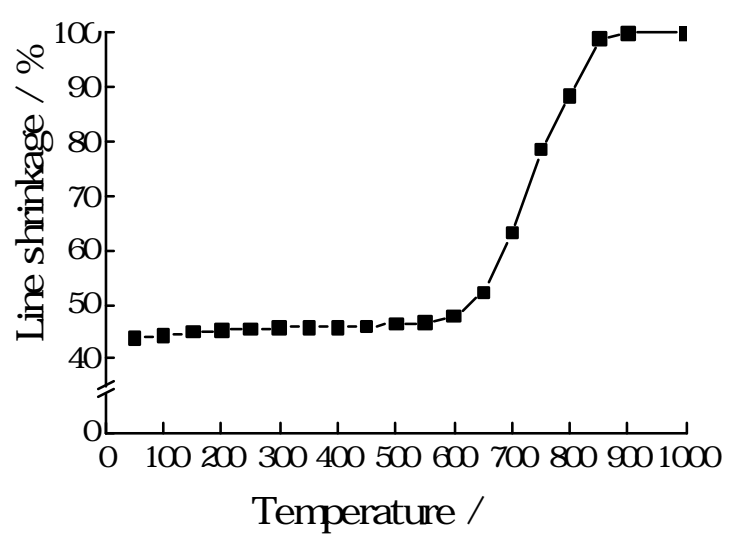

Fig. 8 Line shrinkage of $\mathrm{HA}$ at the indicated temperatures by SPS.
In the sintering process by SPS, the densification started at about $630{ }^{\circ} \mathrm{C}$, and then proceeded with increasing temperature to result in line shrinkage of about $2.2 \mathrm{~mm}$ at $900{ }^{\circ} \mathrm{C}$ (Fig. 8), which means the end of densification.

The HA ceramics sintered by SPS at $800{ }^{\circ} \mathrm{C}$ showed about $90 \%$ relative density, and the ceramics sintered at $900{ }^{\circ} \mathrm{C}$ and $1000{ }^{\circ} \mathrm{C}$ showed over $99 \%$ relative density (Fig. 9).

Whereas in the case of normal sintering in air, densification started at about $900{ }^{\circ} \mathrm{C}^{24}$. These results proved that SPS is a potential method for fabricating highly dense HA ceramics at the much lower temperature like hot-pressing (HP) and hot isostatic pressing (HIP) ${ }^{25-27}$. In particular, sintering period is quite short time.

Although the surfaces of the transparent HA ceramics were slightly rough compared with the surface of tissue culture polystyrene (Fig. 10 (b)) ${ }^{28}$, the grain structure of the surface of the sintered transparent HA ceramic was fine (less than $1 \mathrm{~mm}$ ) (Fig. $10(\text { a) })^{28}$.

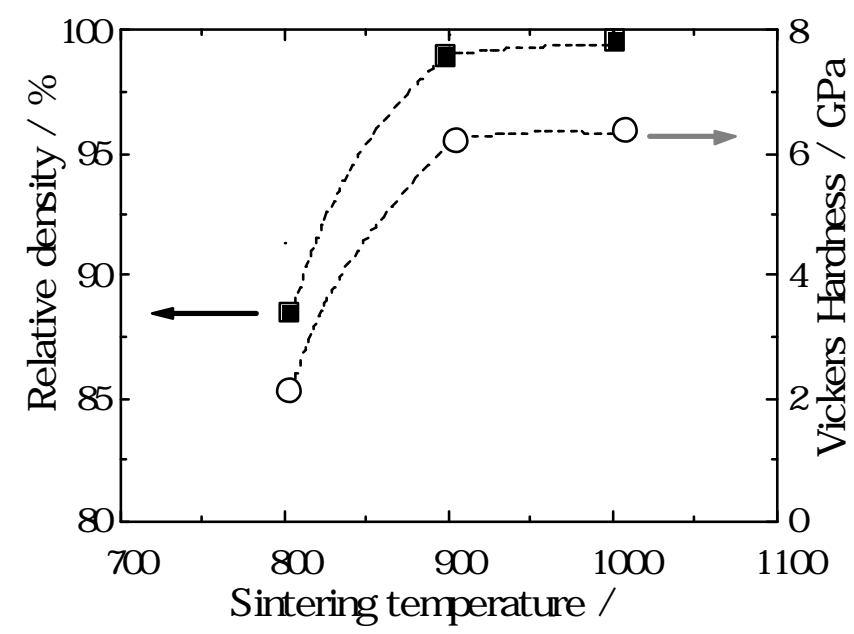

Fig. 9 Relative density and Vickers Hardness of HA ceramics prepared by SPS at various temperatures.

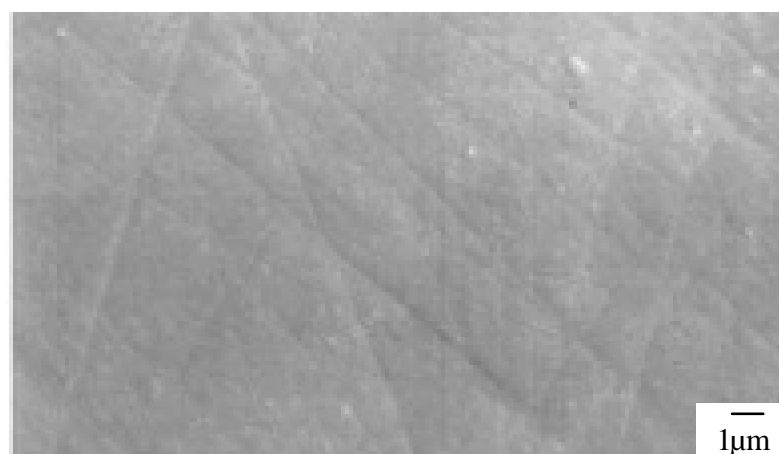

(a)

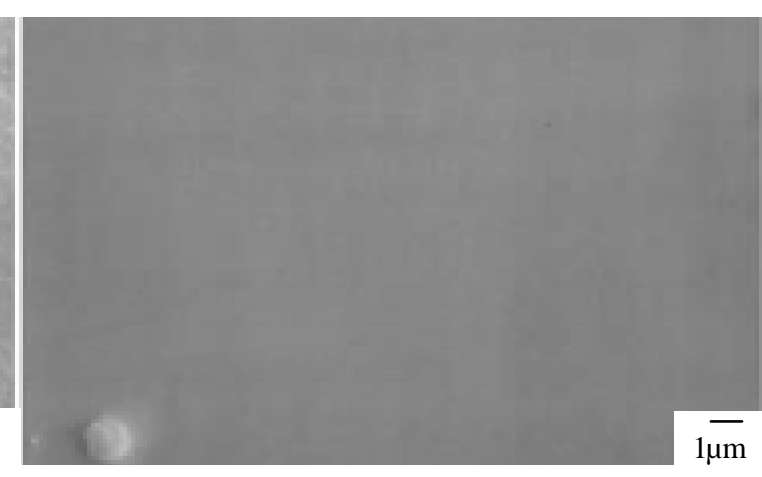

(b)

Fig. 10 SEM image of transparent hydroxyapatite (a) and tissue culture polystyrene dish (b) after N. Kotobuki et al. (Reprinted from ${ }^{28}$ ). 
We also investigated the wettability of transparent HA ceramics and tissue culture polystyrene, which is represented by sessile contact angles (SCA) (Table 1). The SCA of the transparent HA ceramics and the tissue culture polystyrene showed no significant difference.

As transparent HA ceramic material is highly transparent, the cells cultured on transparent HA ceramics could be observed by phase-contrast and fluorescence microscopy. The shapes of the cultured cells on the transparent HA ceramics were clearly detected by phase-contrast microscopy. These results indicate that ordinary cells without fluorescent characteristics can be monitored even when the cells are cultured on HA ceramics (Fig. 11(a) and (b)) ${ }^{28}$. The attachment and spreading were more obvious $5 \mathrm{~h}$ after the seeding (Fig. 11 (e) and (f)) ${ }^{28}$. Most of the cells were able to attach and exhibit the morphological characteristics of mesenchymal types (spindle cell morphology) 1 day after the seeding (Fig. 11 (i) and (j) ${ }^{28}$. The cascade of the cellular response on the transparent HA ceramics was similar to that of the cells seeded on the tissue culture polystyrene (Fig. 11 (c), (d), (g), (h), (k) and (l) $)^{28}$. It is thus suggested that MSC can attach, spread, and proliferate on transparent HA ceramics as well as on tissue culture polystyrene.

Table 1 Ses sile contact angle of transparent HA ceramics after N. Kotobuki et al. (Reprinted from ${ }^{28}$ ).

\begin{tabular}{c}
\hline \multicolumn{2}{c}{ SCA \pm SD } \\
\cline { 2 - 2 } \\
\hline
\end{tabular}

Transparent hydroxyapatite

$73.13 \pm 2.36$

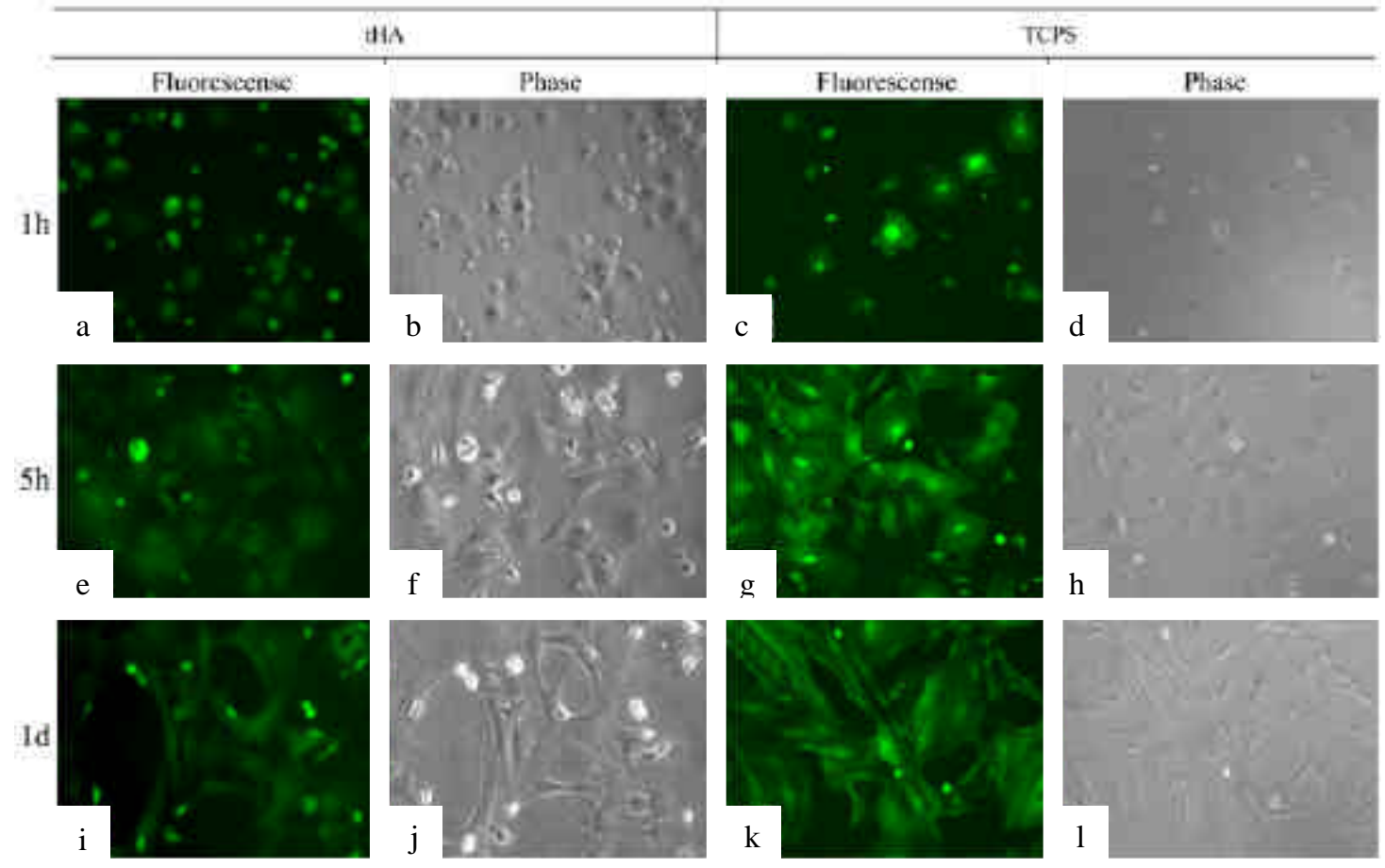

Fig. 11 Cell morphology of rat mesenchymal stem cells (MSC) seeded on transparent hydroxyapatite ceramics and tissue culture polystyrene dishes after N. Kotobuki et al. (Reprinted from ${ }^{28}$ ).

The cells seeded on HA ceramics are seen in (a), (b), (e), (f), (i) and (j).

The cells seeded on tissue culture polystyrene are seen in (c), (d), (g), (h), (k), (l). 
Phosphorous Research Bulletin Vol. 20 (2006) pp. 119-128

In order to analyze the osteogenic differentiation of MSC on transparent HA ceramics, the MSC were cultured on both transparent HA ceramics and tissue culture polystyrene in the presence or absence of dexamethasone (Dex) for 14 days, and cell morphology was observed by phase-contrast microscopy.

The cells differentiated into bone-forming osteoblasts, which fabricate an extracellular mineralized matrix around a clump of the cultured cells. As shown in Fig. 12(a),(b) ${ }^{28}$, the MSC

differentiated into osteoblasts and fabricated a mineralized bone matrix on both the transparent HA ceramics and tissue culture polystyrene. In contrast, the MSC cultured in the absence of Dex (Dex(-)) showed no osteoblastic cell shape but did show a fibroblastic shape (Fig. 12 (c),(d)) ${ }^{28}$ and no evidence of matrix formation. These findings indicate that MSC can easily differentiate into osteoblasts on the surface of transparent HA ceramics, resulting in the formation of bone matrix under conditions of osteogenic culture. Importantly, the cascade of the

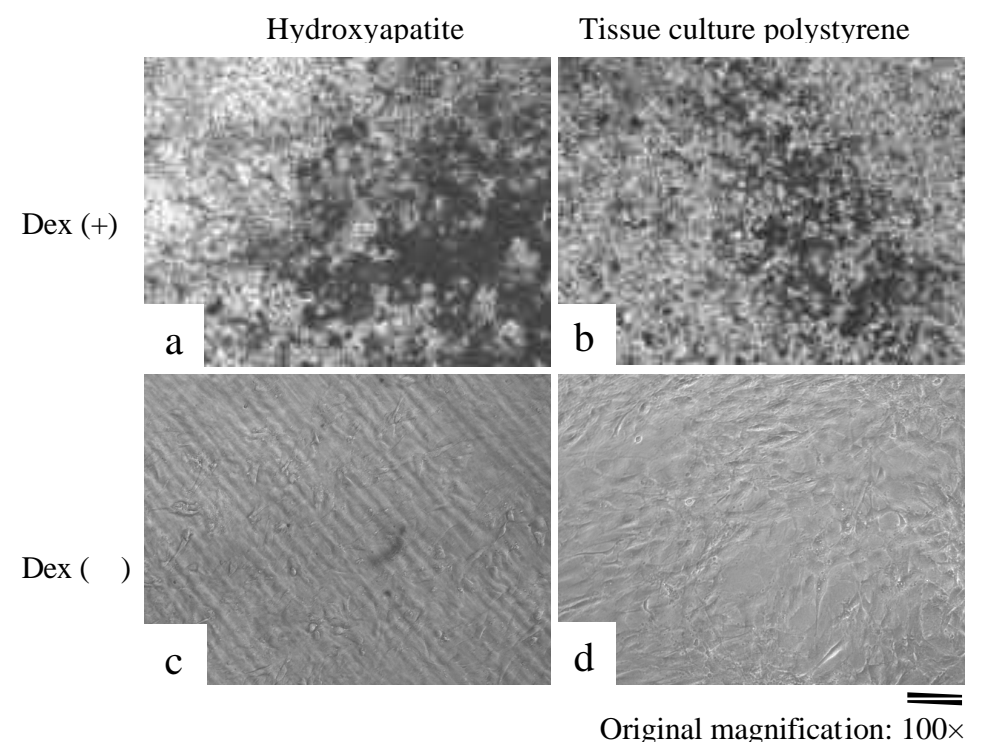

Fig. 12 Cell morphology of rat mesenchymal stem cells (MSC) seeded on transparent hydroxyapatite (a, c) ceramics and tissue culture polystyrene $(b, d)$ dishes in the presence $(+)$ or absence $(-)$ of dexamethasone (Dex) after day 14 of cult ivation after N. Kotobuki et al. (Reprinted from ${ }^{28}$ ).

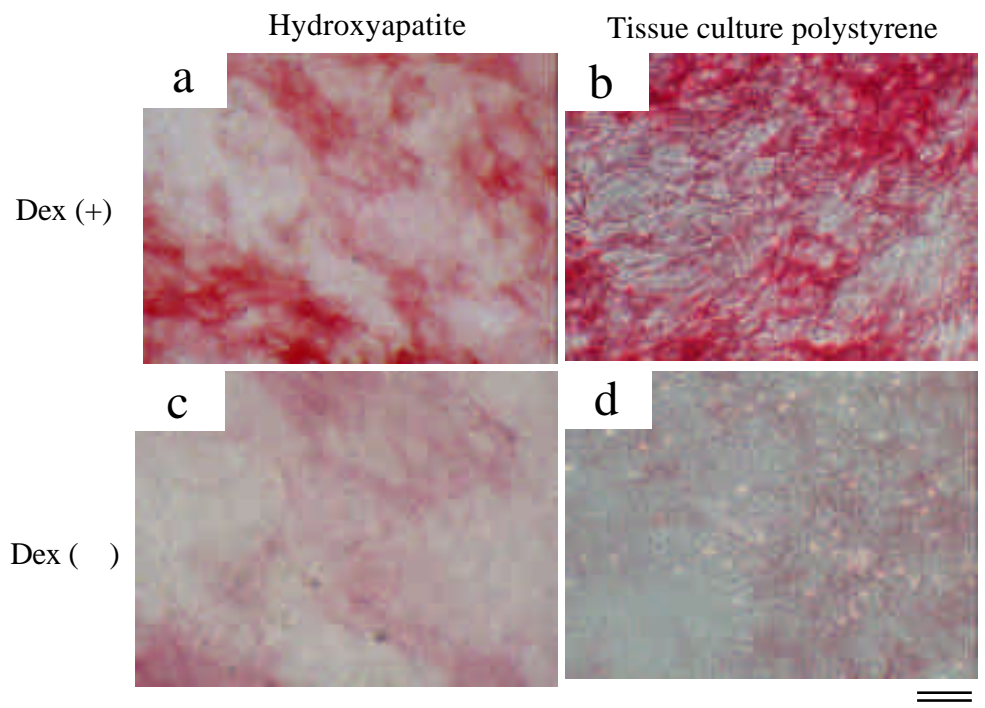

Bar: $1 \mathrm{~mm}$. Double bar: $0.1 \mathrm{~mm}$. Original agnification: $\overline{\overline{100 x}}$

Fig. 13 Alkaline phosphatase (ALP) staining of the cultured cells on day 14 after N. Kotobuki et al. (Reprinted from ${ }^{28}$ ).

Numerous regions of the cultured cells were positive for ALP in the presence of Dexamethasone on HA ceramics (a) and tissue culture polystyrene (b). The positive areas are red. 
Hydroxyapatite
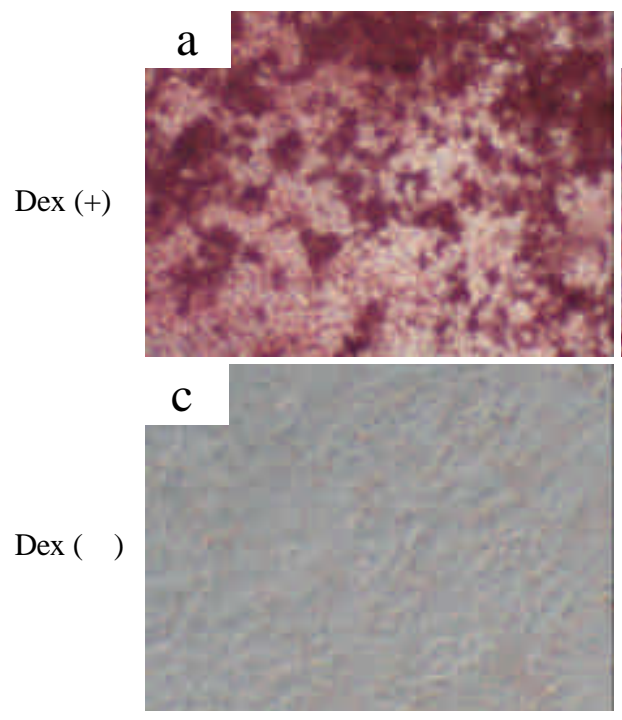

Tissue culture polystyrene
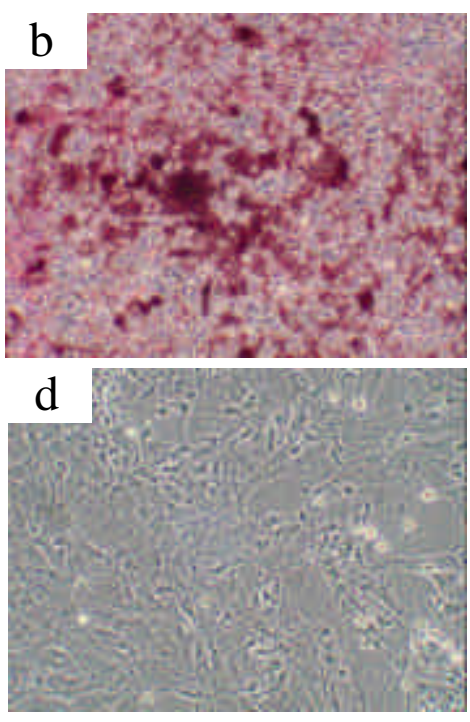

Bar: $1 \mathrm{~mm}$. Double bar: $0.1 \overline{\mathrm{mm}}$

Fig. 14 Calcium staining of the cultured cells with Alizarin Red $S$ on day 14 after N. Kotobuki et al. (Reprinted from ${ }^{28}$ ).

Many Alizarin Red stainable regions of the cultured cells could be detected in the presence of Dense HA ceramics (a) and tissue culture polystyrene (b); the stain was at almost basal levels for cells cultured in the absence of Dense HA ceramics (c) and tissue culture polystyrene (d).

differentiation of MSC can be observed equally on both transparent HA ceramics and tissue culture polystyrene.

To confirm the osteogenic differentiation of MSC on transparent HA ceramics, we stained the cells with alkaline phosphatase (ALP) and calcium staining (Alizarin Red S) after 2 weeks of cultivation. ALP, which is a cell surface protein, is known as an early marker for osteoblastic differentiation. Faint ALP stains on both the transparent HA ceramics (Fig. 13 (a)) ${ }^{28}$ and tissue culture polystyrene (Fig. 13 (d)) ${ }^{28}$ were detected in the culture without Dex, but the stains were much more extensive in the culture with $\operatorname{Dex}(\text { Fig. } 13(a, b))^{28}$.

Alizarin Red $\mathrm{S}$ stain is commonly used to demonstrate calcium deposits. As seen in the ALP stain, the Dex-treated cells were strongly stained with Alizarin Red S (Fig. 14 (a), (b)) ${ }^{28}$, while the cells not treated with Dex were hardly stained (Fig. 14 (c), (d)) 28 . This biochemical data showed that the osteogenic differentiation of MSC cultured in the presence of Dex could occur on both transparent HA ceramic and tissue culture polystyrene substrate.

\section{CONCLUSIONS}

The quantity of $\mathrm{OH}$ in $\mathrm{HA}$ ceramics sintered by SPS was decreased with increasing temperature. Transparent HA ceramics were obtained by SPS at
$900{ }^{\circ} \mathrm{C}$ for $10 \mathrm{~min}$ and $1000{ }^{\circ} \mathrm{C}$ for $10 \mathrm{~min}$. In analysis of sintering of HA on SPS, dominant sintering mechanism of SPS was plastic flow.

Cell attachment, proliferation, and osteogenic differentiation of rat mesenchymal stem cells on transparent HA ceramics observed by light microscopy were significantly similar to those on tissue culture polystyrene dish. The observation of living cells on transparent HA ceramics is a new significant and revealed reliable nature of the HA ceramics for the purpose of tissue engineering in hard tissue repair.

\section{ACKNOWLEDGMENTS}

This work was supported by a 21 st Century COE Program Grant of the International COE of Flow Dynamics from Ministry of Education, Culture, Sports, Science and Technology, and also supported by the Three-Dimensional Tissue Module Project of METI (a Millennium Project) and Grant-in-Aid for Scientific Research Japan.

The authors thank Profs A. Kawasaki and E. Kou, Dr. K. Kikuchi of Tohoku University, Profs S. Yamamoto and S. Goto of Yamaguchi University for use of the apparatus of spark plasma sintering, and als o thank our colleagues at the National Institute of Advanced Industrial Science and Technology (AIST). 


\section{REFERENCES}

1. H. Aoki, Medical Applications of Hydroxyapatite, (Ishiyaku Euro America, Tokyo and St. Louis, 1994).

2. A. Ito and X. Sun, J. Soc. Inorg. Mater. Japan, 3, 386 (1996).

3. K. Ioku, J. Soc. Inorg. Mater. Japan, 3, 412 (1996).

4. T. Kanazawa, T. Umegaki, H. Monma and K.Yamashita, J. Soc. Inorg. Mater. Japan, No. 210, 261 (1987).

5. T. kanazawa, T. Umegaki and H. Monma, Ceramics, 10, 461 (1975).

6. T. Nishimura, M. Mitomo, H. Hirotsuru and M. Kawahara, J. Mater. Sci. Lett., 14, 1046 (1995).

7. M.Tokita, J. Soc. Powder Technol. Japan, 30, 790 (1993).

8. K. Ioku, D. Kawagoe, H. Toya, H. Fujimori, S. Goto, K. Ishida, A. Mikuni, and H. Mae, Trans. Mater. Res. Soc. Japan, 27, 447 (2002).

9. D. Kawagoe, Y. Koga, N. Yamasaki, H. Fujimori, S. Goto and K. Ioku, Phosphorous Res. Bull., 17, 246 (2005).

10. K. Ioku, Chem. Ind., 52, 360 (2001).

11. H. Fujimori, H. Toya, K. Ioku, S. Goto and M. Yoshimura, Chem. Phys. Lett., No. 325, 383 (2000).

12. H. Ohgushi, M. Okumura, S. Tamai, EC. Shors and AI. Caplan, J. Biomed. Mater. Res., 24, 1563 (1990).

13. H. Ohgushi, M. Okumura, T. Yoshikawa, K. Inoue, N. Senpuke and S. Tamai, J. Biomed. Mater. Res., 26, 885 (1992).

14. H. Ohgushi and AI. Caplan, J. Biomed. Mater. Res., 48, 913 (1999).
15. SC. Mendes, JM. Tibbe, M. Veenhof, K. Bakker, S. Both, PP. Platenburg, FC. Oner, JD. De Bruijn and CA. Van Blitterswijk, Tissue Eng., 8, 911 (2002).

16. JD. de Bruijn, I van den Brink, S. Mendes, R. Dekker, YP. Bovell and CA. van Blitterswijk, Adv. Dent. Res., 13, 74 (1999).

17. N. Kotobuki, M. Hirose, Y. Takakura and H. Ohgushi, Artif. Organs., 28, 33 (2004).

18. M. Kinoshita and Y. Hamano,Yogyo-Kyokai-shi, 80, 239 (1972).

19. K. Umeya, T. Nishikawa and H. Nakajima, J. Ceram. Assoc. Japan, 75, 301 (1967).

20. T. Shimohira, Yogyo-Kyokai-shi, 79, 132 (1971).

21. C. Maniatopoulos, J. Sodek and AH. Melcher, Cell Tissue Res., 254, 317 (1988).

22. H. Ohgushi, Y. Dohi, T. Kaduda, S. Tamai, S. Tabata and Y. Suwa, J. Biomed. Mater. Res., 32, 333 (1996).

23. S. Zhang, K. E. Gonsalves, J. Mater. Sci. Mater. Med., 8, 25 (1997).

24. K. Daimon, W. Min, T. Sugita, Y. Hikichi, T. Matsubara, T. Ota and Y. Kaji, J. Soc. Inorg. Mater. Japan, 8, 283, (2001).

25. K. Ioku, M. Yoshimura and S. Somiya, J. Ceram. Soc. Japan, 96, 109 (1988).

26. K. Ioku, S. Somiya and M. Yoshimura, J. Mater. Sci. Lett., 8, 1230 (1989).

27. K. Ioku, M. Yoshimura and S. Somiya, Biomaterials, 11, 57 (1990).

28. N. Kotobuki, K. Ioku, D. Kawagoe, D. Nomura, H. Fujimori, S. Goto and H. Ohgushi, Key Engineering Materials, 284, 663 (2005). 